\title{
Preemptive and Upfront Plerixafor: Safe and Effective Strategy for Patients Undergoing Autologous Stem Cell Transplant and at High Risk for Mobilization Failure
}

\begin{abstract}
Introduction: Approximately $10 \%-30 \%$ of patients are unable to collect the minimum number of stem cells to support high-dose chemotherapy and autologous stem cell transplant (hematopoietic stem cell transplantation). Plerixafor alone or in combination with granulocyte colony-stimulating factor (G-CSF) has been shown to significantly increase the CD34 cell collection, especially in patients who failed their initial harvest strategy. This is a retrospective study of 17 preselected patients (relapsed lymphoma and myeloma), who were considered to have high risk of mobilization failure and who had undergone upfront and preemptive plerixafor mobilization. Patients and Methods: The mobilization protocol consisted of G-CSF (10-15 $\mu \mathrm{g} / \mathrm{kg}$ ) subcutaneously daily for 4 days before the initiation of plerixafor on evening of day 4 . The patients then underwent apheresis on day 5. Results: Among 17 patients who underwent apheresis, 16 (93\%) yielded the minimum required cell collection of $\geq 2 \times 106 \mathrm{CD} 34+$ cells $/ \mathrm{kg}$ in a single apheresis session ( 2 days). Out of these 16 patients, $8(53 \%)$ patients achieved the minimum target dose in a single day. Eight $(50 \%)$ of all patients achieved the optimum target cell collection in a single apheresis session. Out of these eight patients, five (62\%) patients collected optimum yield in a single day. Conclusion: Plerixafor is safe and effective if used upfront and preemptively for patients in whom mobilization of stem cells is considered to be a problem.
\end{abstract}

Keywords: Autologous stem cell transplant, plerixafor, preemptive upfront

\section{Introduction}

Autologous hematopoietic stem cell transplantation (HSCT) after high-dose chemotherapy is the standard treatment for patients with relapsed non-Hodgkin's lymphoma (NHL) and myeloma. ${ }^{[1,2]}$ The success of transplant depends on the number of hematopoietic stem cells collected.

Approximately $10 \%-30 \%$ of patients are unable to collect the minimum number of stem cells, defined as $2 \times 10^{6} \mathrm{CD} 34$ cells $/ \mathrm{kg}$, to support high-dose chemotherapy and autologous HSCT. ${ }^{[3]}$ Plerixafor (AMD3100) reversibly inhibits chemokine stromal cell-derived factor-1 binding to its cognate receptor CXC chemokine receptor 4 . Plerixafor alone or in combination with granulocyte colony-stimulating factor (G-CSF) has been reported in various clinical studies (Phase 2), to significantly increase the number of peripheral blood (PB) CD34 cells and CD34 cell

This is an open access journal, and articles are distributed under the terms of the Creative Commons Attribution-NonCommercial-ShareAlike 4.0 License, which allows others to remix, tweak, and build upon the work non-commercially, as long as appropriate credit is given and the new creations are licensed under the identical terms.

For reprints contact: WKHLRPMedknow_reprints@wolterskluwer.com collection, especially in patients who failed their initial harvest strategy. ${ }^{[4]}$

Two subsequent large Phase III trials of upfront plerixafor plus G-CSF (P + G-CSF) mobilization confirmed that the combination was associated with higher CD34 cell yields, better achievement of collection targets, lower failure rates, and fewer apheresis sessions compared with G-CSF alone. ${ }^{[5-9]}$

This is a retrospective study of 17 preselected patients (relapsed lymphoma and myeloma after first best response), who were considered to have high risk of mobilization failure and who had undergone upfront and preemptive plerixafor.

\section{Study Design and Patients and Methods}

Eligibility and exclusion criteria

This is a retrospective study of 17 preselected patients (relapsed lymphoma

How to cite this article: Sheth $V$, Jain $R$, Gore A, Ghanekar A, Saikia T. Preemptive and upfront plerixafor: Safe and effective strategy for patients undergoing autologous stem cell transplant and at high risk for mobilization failure. Indian $\mathrm{J}$ Med Paediatr Oncol 2020;41:19-22.

\section{Vipul Sheth ${ }^{1,2, *}$, Reetu Jain ${ }^{1,3, *}$, Adwaita Gore ${ }^{1, *}$, Amit Ghanekar ${ }^{1}$, Tapan Saikia ${ }^{1}$}

${ }^{1}$ Department of Bone Marrow Transplantation and Medical Oncology, Prince Aly Khan Hospital, Mumbai, Maharashtra, India, ${ }^{2}$ Fred Hutchison Cancer Centre, Seattle, Washington, USA, ${ }^{3}$ Department of Hematology and Bone Marrow Transplant Jaslok Hospital and Research Centre, Mumbai, Maharashtra, India

*These authors equally contributed to this work

Submitted: 24-Feb-2019

Revised: 10-Nov-2019

Accepted: 13-Dec-2019

Published: 24-Apr-2020

Address for correspondence: Dr. Vipul Sheth,

Fred Hutchison Cancer

Research Centre, Washington

University, Seattle, Washington,

USA.

E-mail:drvipulsheth@gmail. com

Access this article online

Website: www.ijmpo.org

DOI: 10.4103/ijmpo.ijmpo_46_19

Quick Response Code:

a:3hris

texpla

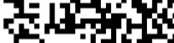

Airypr

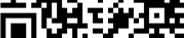


and myeloma after initial best response) considered high risk for failed mobilization and who had undergone transplant postplerixafor mobilization at a single tertiary care center.

The mobilization protocol consisted of G-CSF (10-15 $\mu \mathrm{g} / \mathrm{kg})$ subcutaneously daily for 4 days before the initiation of plerixafor. Plerixafor (0.24 $\mathrm{mg} / \mathrm{kg}$, Mozobil) was then administered subcutaneously on the evening of day 4. Patients underwent apheresis on day 5 approximately $10-11 \mathrm{~h}$ after the dose of plerixafor. Plerixafor, G-CSF, and apheresis were continued for up to until $\geq 2 \times 10^{6} \mathrm{CD} 34+$ (or whatever was considered to be optimal) cells had been collected.

The study was approved by the hospital ethical committee.

\section{Study objectives}

The primary study objective was to assess the efficacy of plerixafor and G-CSF as a mobilization regimen, as measured by the number of patients having minimum $\left(\geq 2 \times 10^{6} \mathrm{CD} 34+\right.$ cells $\left./ \mathrm{kg}\right)$ and optimum $\left(\geq 5 \times 10^{6} \mathrm{CD} 34+\right.$ cells $/ \mathrm{kg}$ for NHL and Hodgkin's disease or $\geq 6 \times 10^{6} \mathrm{CD} 34+$ cells $/ \mathrm{kg}$ for multiple myeloma [MM]), and the number of days required to do so. Secondary objectives were to assess the clinical effectiveness of plerixafor and G-CSF-mobilized stem cells by examining hematopoietic cell engraftment and graft durability and confirm the safety of mobilization and survival.

\section{Statistical methods}

Categorical variables were summarized as frequency counts and continuous variables as mean or median. Survival was calculated using the Kaplan-Meier Survival method. IBM statistical package for windows version 24, Armonk, New York, USA was used for all the analyses.

\section{Results}

\section{Demographic characteristics}

A total of 17 patients were given plerixafor. The demographics of patients included in the study are shown in Table 1. The risk factors predicting failed mobilization are given in Table 2. Eight (50\%) patients had myeloma and nine patients $(50 \%)$ had lymphoma.

\section{Mobilization}

Among 17 patients who underwent apheresis, $16(93 \%)$ yielded the minimum required cell collection of $\geq 2 \times 10^{6}$ $\mathrm{CD} 34+$ cells $/ \mathrm{kg}$ in a single apheresis session (2 days). According to the disease status, eight $(87 \%)$ patients within the NHL group and eight $(100 \%)$ patients within the MM group yielded the minimum target cell collection. Out of these 16 patients, $8(53 \%)$ patients achieved the minimum target dose in a single day.

Eight $(50 \%)$ of all patients achieved the optimum target cell collection (i.e., $\geq 5 \times 10^{6} \mathrm{CD} 34+$ cells $/ \mathrm{kg}$ for lymphoma

\begin{tabular}{lc}
\hline \multicolumn{2}{l}{ Table 1: Demographic characteristics of patients $(\boldsymbol{n}=\mathbf{1 7})$} \\
\hline Demographic profile & Number $\mathbf{( \% )}$ \\
\hline Age & $57(42-63)$ \\
Myeloma & $36(14-58)$ \\
Lymphoma & \\
Gender: Male, $n(\%)$ & $4(50)$ \\
Myeloma & $5(62)$ \\
Lymphoma & \\
Diagnosis, $n(\%)$ & $8(50)$ \\
Myeloma & $9(50)$ \\
Lymphoma & \\
Conditioning regime, $n(\%)$ & $3(25)$ \\
BACE & $5(62)$ \\
LACE & $1(12)$ \\
BEAM & $8(100)$ \\
Melphalan (myeloma)
\end{tabular}

$\mathrm{B}$ - Carmustine; A - Cytosine arabinoside; E - Etoposide; C - Cyclophosphamide; M - Melphalan; L - Lomustine

or $\geq 6 \times 10^{6} \mathrm{CD} 34+$ cells $/ \mathrm{kg}$ for $\mathrm{MM}$ ) in a single apheresis session. According to disease status, two (25\%) patients within the lymphoma group and six (75\%) patients within the MM group achieved the optimum target cell collection. Out of these eight patients, five $(62 \%)$ patients collected optimum yield in a single day. The median total number of all CD34+ cells collected over 2 days was $3.4 \times 10^{6}$ CD34+ cells/kg (range: $1.5-16$ cells $/ \mathrm{kg}$ ), [Table 3].

Only one patient did not yield adequate number of cells in one session of apheresis. He was a case of heavily pretreated transformed lymphoma. However, we could get optimal yield in second session which was carried out after 10 days. The median number of days of apheresis for minimal collection $\left(2 \times 10^{6}\right.$ cells $\left./ \mathrm{kg}\right)$ was 2 days for lymphoma 1.5 days for myeloma.

\section{Transplantation and engraftment}

Thirteen $(86 \%)$ of the 17 patients who underwent transplantation achieved neutrophil engraftment and $9(60 \%)$ of 17 patients achieved platelet engraftment within 15 days of transplantation. The median times to neutrophil and platelet engraftment were 11 days (range: 8-15, one patient did not engraft and expired) and 12 days (range: 10-29, four patients did not engraft till the day +15 , and one patient expired), respectively.

One hundred percent of patients received G-CSF posttransplantation. Six patients had completed 100-day follow-up in myeloma, and the progression-free and overall survivals were $100 \%$ for myeloma. Seven patients (one expired) had completed 100-day follow-up in lymphoma, and progression-free survival was $75 \%$ and overall survival was $87 \%$.

\section{Discussion}

PB stem cell collection is the standard of care at present. Factors predicting mobilization practices take into 
Table 2: Poor mobilizing factors for the patients undergoing mobilization with plerixafor

\begin{tabular}{lcc}
\hline & Myeloma $(\boldsymbol{n}=\mathbf{8})$ & Lymphoma $(\boldsymbol{n}=\mathbf{9})$ \\
\hline Age (years), median (range) & $57(47-63)$ & $36(14-58)$ \\
Prior chemotherapy regimen $>2, n(\%)$ & $2(25)$ & $2(25)$ \\
Number of cumulative prior chemotherapy cycles $>10, n(\%)$ & $3(37)$ & $8(100)$ \\
Number of patients with prior lenalidomide treatment, $n(\%)$ & $4(50)$ & 0 \\
Number of patients with prior radiotherapy, $n(\%)$ & $2(25)$ & $2(25)$ \\
Number of patients who had undergone prior auto-HSCT, $n(\%)$ & $1(12)$ & 0 \\
\hline
\end{tabular}

HSCT - Hematopoietic stem cell transplantation

\begin{tabular}{lcc}
\hline \multicolumn{1}{c}{ Table 3: Efficacy of plerixafor as mobilization agent } & & \\
\hline & MM $(\boldsymbol{n}=\mathbf{8})$ & Lymphoma $(\boldsymbol{n}=\mathbf{9})$ \\
\hline $\mathrm{CD} 34+$ cells $/ \mathrm{kg} \times 10^{6}$ collected, median (range) & $5.5(1.5-8.8)$ & $2.4(2-16)$ \\
Number of patients yielding minimal cell dose $\left(\geq 2 \times 10^{6} \mathrm{CD} 34+\right.$ cells $\left./ \mathrm{kg}\right), n(\%)$ & $8(100)$ & $7(87)$ \\
Days to collect minimal cell dose, median (range) & $1.5(1-3)$ & $2(1-4)$ \\
Number of patients that obtained minimum target in a single day, $n(\%)$ & $8(53)$ \\
Number of patients yielding optimal cell dose $\left(\geq 5 \times 10^{6} \mathrm{NHL}\right.$ and $\geq 6 \times 10^{6}, \mathrm{MM} \mathrm{CD} 34+$ cells $\left./ \mathrm{kg}\right), n(\%)$ & $6(75)$ & $2(25)$ \\
Number of patients who yielded optimum yield in a single day, $n(\%)$ & & $5(62)$ \\
\hline
\end{tabular}

NHL - Non-Hodgkin's lymphoma; MM - Multiple myeloma

consideration the number of chemotherapy cycles given earlier, agents used and type of disease (stage and remission status), age of patient, prior radiation, and lenalidomide pretreatment. ${ }^{[10-12]}$

The optimal target of $5 \times 10^{6} \mathrm{CD} 34$ cells $/ \mathrm{kg}$ was selected because transplantation with this cell dose is associated with prompt and durable engraftment. ${ }^{[13-15]}$ Increasing the G-CSF does improve on this, but it is still associated with some failure rates. ${ }^{[16]}$ Chemotherapy-based mobilization regimens may further improve mobilization rates further but with added toxicities. ${ }^{[17,18]}$

Plerixafor is usually used in subgroup of patients having failed mobilization with conventional agents such as chemomobilization or G-CSF mobilization. ${ }^{[19]}$ These data were analyzed to study the effect of upfront preemptive plerixafor mobilization in a cohort of patients having high chances of mobilization failure.

The number of patients who yielded the optimum target cell collection of $\geq 5 \times 10^{6} \mathrm{CD} 34+$ cells $/ \mathrm{kg}$ for $\mathrm{NHL}$ or $\geq 6 \times 10^{6} \mathrm{CD} 34+$ cells $/ \mathrm{kg}$ for MM in a median of 2 days of apheresis (one session) by disease group was $2(25 \%)$ for patients with NHL and $6(75 \%)$ for patients with MM. The optimum yield of $5 \times 10^{6} \mathrm{CD} 34$ cells in PREDICT study (115 patients, 90 patients with myeloma and 25 with lymphoma) was $80(89 \%)$ in myeloma and $12(48 \%)$ in lymphoma. The optimum yield obtained in our study was lesser than other groups probably because we did our stem cell collection at the end of salvage treatment as compared to earlier collection in other groups. ${ }^{[20]}$

Peripheral CD34 has been the most important factor in predicting outcomes of mobilization as per other studies. ${ }^{[21]}$ Costa et al. ${ }^{[22]}$ used center-specific cost simulation to develop preestablished PB CD34 thresholds at which plerixafor would be added to improve collection efficiency and reduce the cost of mobilization attempts. In future studies, algorithms, using PB CD34 on day 4 of G-CSF, daily yield, and risk factors predicting mobilization failure could be taken into account for deciding on days of plerixafor needed for optimal yield. We could not involve PB CD34 in addition to risk factors for poor mobilization in our approach to preemptive plerixafor, as we do not have in-house CD34 testing (but this is the problem with majority of centers across the country). This along with a small sample size (relatively new strategy) remains a major drawback to the study.

It is worth mentioning that four patients had received prior lenalidomide treatment. All of them achieved minimal yield of $2 \times 106 \mathrm{CD} 34$ cells $/ \mathrm{kg}$. Three out of four patients $(75 \%)$ achieved optimal yield of $6 \times 106 \mathrm{CD} 34 / \mathrm{kg}$ in a single apheresis session. Overall, prior lenalidomide treatment made no difference to final product yield. Furthermore, at the time of this study, generic plerixafor was not available. There is indeed a huge cost difference between generic $(25,000-30,000)$ and Mozobil. (55,000-60,000) Implementing generics in future will certainly further bring down further upon the cost of this approach, which would be significantly lower than an additional apheresis session. Furthermore, the yield reduces with every passing apheresis session (especially in high-risk patients), and this strategy can significantly reduce the chances of mobilization failure, as well as bring down the burden of extra costings and time of an additional apheresis.

\section{Conclusion}

Plerixafor is safe and effective if used upfront and preemptively for patients in whom mobilization of stem 
cells is considered to be a problem. There is a need to study this strategy in a prospective manner in future.

Authorship contribution: VS, AG and RJ contributed equally, wrote the manuscript, analyzed the data, and designed the study; AG treated patients; RJ mentored paper and treated patients, TS mentored paper and treated patients.

All procedures performed in studies involving human participants were in accordance with the ethical standards of the institutional and/or national research committee and with the 1964 Helsinki declaration and its later amendments or comparable ethical standards.

\section{Financial support and sponsorship}

Nil.

\section{Conflicts of interest}

There are no conflicts of interest.

\section{References}

1. Philip T, Guglielmi C, Hagenbeek A, Somers R, Van der Lelie H, Bron $\mathrm{D}$, et al. Autologous bone marrow transplantation as compared with salvage chemotherapy in relapses of chemotherapy-sensitive non-Hodgkin's lymphoma. N Engl J Med 1995;333:1540-5.

2. Shipp MA, Abeloff MD, Antman KH, Carroll G, Hagenbeek A, Loeffler $\mathrm{M}$, et al. International consensus conference on high-dose therapy with hematopoietic stem cell transplantation in aggressive non-Hodgkin's lymphomas: Report of the jury. J Clin Oncol 1999;17:423-9.

3. Kuittinen T, Nousiainen T, Halonen P, Mahlamäki E, Jantunen E. Prediction of mobilisation failure in patients with non-Hodgkin's lymphoma. Bone Marrow Transplant 2004;33:907-12.

4. Flomenberg N, Devine SM, Dipersio JF, Liesveld JL, McCarty JM, Rowley SD, et al. The use of AMD3100 plus G-CSF for autologous hematopoietic progenitor cell mobilization is superior to G-CSF alone. Blood 2005;106:1867-74.

5. DiPersio JF, Micallef IN, Stiff PJ, Bolwell BJ, Maziarz RT, Jacobsen E, et al. Phase III prospective randomized double-blind placebo-controlled trial of plerixafor plus granulocyte colony-stimulating factor compared with placebo plus granulocyte colony-stimulating factor for autologous stem-cell mobilization and transplantation for patients with non-Hodgkin's lymphoma. J Clin Oncol 2009;27:4767-73.

6. DiPersio JF, Stadtmauer EA, Nademanee A, Micallef IN, Stiff PJ, Kaufman JL, et al. Plerixafor and G-CSF versus placebo and G-CSF to mobilize hematopoietic stem cells for autologous stem cell transplantation in patients with multiple myeloma. Blood 2009;113:5720-6.

7. Ogunniyi A, Rodriguez M, Devlin S, Adel N, Landau H, Chung DJ, et al. Upfront use of plerixafor and granulocyte-colony stimulating factor (GCSF) for stem cell mobilization in patients with multiple myeloma: Efficacy and analysis of risk factors associated with poor stem cell collection efficiency. Leuk Lymphoma 2017;58:1123-9.

8. Douglas KW, Gilleece M, Hayden P, Hunter H, Johnson PRE, Kallmeyer C, et al. UK consensus statement on the use of plerixafor to facilitate autologous peripheral blood stem cell collection to support high-dose chemoradiotherapy for patients with malignancy. J Clin Apher 2018;33:46-59.

9. Afifi S, Adel NG, Devlin S, Duck E, Vanak J, Landau H, et al. Upfront plerixafor plus G-CSF versus cyclophosphamide plus G-CSF for stem cell mobilization in multiple myeloma: Efficacy and cost analysis study. Bone Marrow Transplant 2016;51:546-52.

10. Morris CL, Siegel E, Barlogie B, Cottler-Fox M, Lin P, Fassas A, et al. Mobilization of $\mathrm{CD} 34+$ cells in elderly patients $(>/=70$ years) with multiple myeloma: Influence of age, prior therapy, platelet count and mobilization regimen. $\mathrm{Br} \mathrm{J}$ Haematol 2003;120:413-23.

11. Kumar S, Dispenzieri A, Lacy MQ, Hayman SR, Buadi FK, Gastineau DA, et al. Impact of lenalidomide therapy on stem cell mobilization and engraftment post-peripheral blood stem cell transplantation in patients with newly diagnosed myeloma. Leukemia 2007;21:2035-42.

12. Paripati H, Stewart AK, Cabou S, Dueck A, Zepeda VJ, Pirooz N, et al. Compromised stem cell mobilization following induction therapy with lenalidomide in myeloma. Leukemia 2008;22:1282-4.

13. Rosenkilde MM, Gerlach LO, Hatse S, Skerlj RT, Schols D, Bridger GJ, et al. Molecular mechanism of action of monocyclam versus bicyclam non-peptide antagonists in the CXCR4 chemokine receptor. J Biol Chem 2007;282:27354-65.

14. Jillella AP, Ustun C. What is the optimum number of CD34+ peripheral blood stem cells for an autologous transplant? Stem Cells Dev 2004;13:598-606.

15. Bolwell BJ, Pohlman B, Rybicki L, Sobecks R, Dean R, Curtis J, et al. Patients mobilizing large numbers of $\mathrm{CD} 34+$ cells ('super mobilizers') have improved survival in autologous stem cell transplantation for lymphoid malignancies. Bone Marrow Transplant 2007;40:437-41.

16. Kröger N, Zeller W, Fehse N, Hassan HT, Krüger W, Gutensohn $\mathrm{K}$, et al. Mobilizing peripheral blood stem cells with high-dose G-CSF alone is as effective as with Dexa-BEAM plus G-CSF in lymphoma patients. Br J Haematol 1998;102:1101-6.

17. Desikan KR, Barlogie B, Jagannath S, Vesole DH, Siegel D, Fassas A, et al. Comparable engraftment kinetics following peripheralblood stem-cell infusion mobilized with granulocyte colony-stimulating factor with or without cyclophosphamide in multiple myeloma. J Clin Oncol. 1998; 16:1547-1553.

18. Koç ON, Gerson SL, Cooper BW, Laughlin M, Meyerson H, Kutteh L, et al. Randomized cross-over trial of progenitor-cell mobilization: High-dose cyclophosphamide plus granulocyte colony-stimulating factor (G-CSF) versus granulocyte-macrophage colony-stimulating factor plus G-CSF. J Clin Oncol 2000;18:1824-30.

19. Devine SM, Flomenberg N, Vesole DH, Liesveld J, Weisdorf D, Badel $\mathrm{K}$, et al. Rapid mobilization of $\mathrm{CD} 34+$ cells following administration of the CXCR4 antagonist AMD3100 to patients with multiple myeloma and non-hodgkin's lymphoma. J Clin Oncol 2004;22:1095-102.

20. Russell N, Douglas K, Ho AD, Mohty M, Carlson K, Ossenkoppele GJ, et al. Plerixafor and granulocyte colony-stimulating factor for first-line steady-state autologous peripheral blood stem cell mobilization in lymphoma and multiple myeloma: Results of the prospective PREDICT trial. Haematologica 2013;98:172-8.

21. Abhyankar S, DeJarnette S, Aljitawi O, Ganguly S, Merkel D, McGuirk J. A risk-based approach to optimize autologous hematopoietic stem cell (HSC) collection with the use of plerixafor. Bone Marrow Transplant 2012;47:483-7.

22. Costa LJ, Alexander ET, Hogan KR, Schaub C, Fouts TV, Stuart RK. Development and validation of a decision-making algorithm to guide the use of plerixafor for autologous hematopoietic stem cell mobilization. Bone Marrow Transplant 2011;46:64-9. 